\title{
KASVATUKSEN HISTORIAN ENSIMMÄISET SUOMALAISET KESÄPÄIVÄT
}

Turun yliopistossa tehtiin kasvatushistoriallisen tai kasvatuksen historiallisen - sananvalinnasta riittänee keskustelua jatkossakin - tutkimuksen historiaa 2.-3. kesäkuuta. Samaan aikaan, kun ainoaa ja ehkä viimeistä kasvatushistorian oppituolia oltiin ajamassa alas kaikinpuolin huippuisessa Suomen maassa, kasvatushistorian tai kasvatuksen historian tutkijat kokoontuivat alan ensimmäisille omille kesäpäiville. Taustalla oli niin Suomen Kasvatustieteellisen Seuran perustama kasvatushistorian erityisryhmä kuin monien yksittäisten tutkijoiden pitkäkestoinen kiinnostus ja huoli kasvatuksen historiallisen ja historiallis- tavan tutkimuksen tilasta Suomessa.

Vaikka aloitteen takana oli varsin tukeva ryhmä, tapahtuman käytännön toteuttajina olivat Turun yliopiston kasvatustieteiden laitoksen ja CELEn (elinikäisen oppimisen ja opetuksen tutkimusyksikön) järjestelytoimikunta, Annukka Jauhiainen, Marjo Nieminen, Sirkku Rautakilpi, Juhani Tähtinen, Arja Virta ja Minna VuorioLehti, jotka organisoivat tapahtuman leppoisasti, mutta tehokkaasti.

Tapahtuman tarkoituksena oli hahmottaa yhtäältä kasvatuksen historiallisen tutkimuksen nykytilaa, toisaalta sen monitieteellistä ja meto- 
dologista moninaisuutta sekä kolmanneksi sen paikallisuuden merkitystä. Kasvatuksen historiallisen tutkimuksen hiipumista ja marginaalisuutta niin kasvatus- kuin historiatieteissä ajatellen seminaari herätti yllättävän laajaa kiinnostusta: mukana oli yli 70 kasvatushistoriallista tutkimusta tekevää tai siitä kiinnostunutta ihmistä eri puolilta Suomea ja muutamia ulkomailtakin.

Seminaarin ohjelma oli rakennettu ensisijaisesti osanottajien omien tutkimusten esittelyn ja käsittelyn varaan. Teemoina olivat 1) kasvatuksen historian tutkimusaineistot ja -menetelmät, 2) ammatti, koululaitos ja opetusmenetelmät ja 3) aatteet ja aikakaudet, mutta myös paikallisten historian tutkijoiden organisoimiin metodologisiin työpajoihin suullisen/muistitiedon historiasta, kuvista historiallisina lähteinä ja ns. arkipäivän lähteistä.

Yhteisissä sessioissa Risto Rinne hahmotti omasta - tosin varsin turkulaisesta - perspektiivistään kasvatuksen historiallisen tutkimuksen tilaa Suomessa. Anne Ollila taas demonstroi ajankohtaista historiatieteellistä lähestymistapaa analysoidessaan kasvatuksen ruumiillisuutta Norbert Eliasin ranskalaisen hovielämän sivilisatorisen tulkinnan kautta.

Teemaryhmissä saatiin ilahduttavasti kuulla jatko-opiskelijoiden esityksiä kasvatushistoriallisista aiheistaan. Niitä riitti aatteiden ja aikakausien tutkimuksesta tai ammattien, koululaitoksen ja opetusmenetelmien tutkimuksesta kasvatuksen historian tutkimusaineistoihin ja -menetelmiin asti. Lisäksi päivien osanottajat osallistuivat Turun yliopiston yleisen, poliittisen ja kulttuurihistorian tutkijoiden järjestämiin metodologisiin työpajoihin, joissa pohdittiin suullisen ja muistitiedon, arkipäivän historian ja kuvallisen historian merkityksiä kasvatushistorian tutkimuksessa.

\section{YHTEINEN KIINNOSTUS YHDISTI}

Tärkeintä päivissä oli se, että suomalaiset kasvatuksen historiasta kiinnostuneet tutkijat saivat tavata toisiaan ja todeta yhteisen halun pitää yllä ja vahvistaa kasvatuksen historiallistavaa näkökulmaa niin kasvatustyön käytänteissä kuin tutkimuksessakin. Kiinnostus yhteiseen tutkimusalueeseen ylitti niin kasvatustieteiden eri osa-alueet kuin tutkijoiden järjestäytymisenkin. Päivien yleiskokouksessa todettiin kasvatuksen historian alan kaipaavan juuri tällaista yhteistyötoimintaa ja -verkostoa. Samalla nähtiin erittäin tärkeäksi, että ryhmä toimii avoimuuden periaatteella: ryhmän toimintaan ja tilaisuuksiin ovat tervetulleita niin perusopiskelijat, jatko-opiskelijat, tutkijat kuin alan emerituksetkin.

Kokous päätti perustaa seuraavalle kaksivuotiskaudelle johtoryhmän, johon valittiin seuraavaksi kaksivuotiskaudeksi professori Anja Heikkinen (Tay), erikoissuunnittelija Risto Ikonen (Joy), professori Jukka Rantala (HY), professori Marjatta Rahikainen (HY) ja ryhmän puheenjohtajaksi Juhani Tähtinen (Tuy). Päätettiin myös, että ryhmä pitää vuotuisen yleiskokouksensa Kasvatuksen historian päivien yhteydessä.

Erittäin merkittävä lähtökohta ryhmän toiminnan organisoinnissa on kasvatuksen ja kasvatustieteiden eri osa-alueiden kokoaminen yhteen ja tiiviin yhteyden luominen historiatieteisiin ja Suomen Historialliseen Seuraan.

Johtoryhmä päätti kokouksessaan, että kasvatuksen historian päivät pidetään kerran vuodessa ja toiminnan kehittämisessä noudatetaan hitaan etenemisen politiikkaa. Päivien järjestämisen ohessa johtoryhmä näki tärkeimmäksi tehtäväksi ryhmän kotisivujen kehittämisen, kansallisen ja kansainvälisen yhteistyöverkoston luomisen ja alan julkaisutoiminnan edistämisen. Vuoden 2006 kasvatushistorian kesäpäivät lupautui järjestämään Anja Heikkinen, johon päivien organisoimisesta kiinnostuneet voivat ottaa yhteyttä: anja.heikkinen@uta.fi.

Vuoden 2007 päivien pitopaikaksi päätettiin Helsinki. Lisäksi kasvatuksen historian ryhmä järjestää oman teemaryhmän kasvatustieteen päiville syksyllä 2005 http://www.kasvatus.net/kasvatustieteenpaivat/ ja tarpeen mukaan muihin tieteellisiin tapahtumiin. Kasvatuksen historiasta kiinnostuneille ryhmä on valmistamassa omaa kotisivustoa, jonka valmiustilasta voi konsultoida ryhmän puheenjohtajaa Juhani Tähtistä: juhani.tahtinen@utu.fi.

\section{Anja Heikkinen}

